\title{
Infusa Daun Salam Mempertahankan Kualitas dan Daya Tahan Daging Sapi Bali
}

(BAY LEAVES INFUSE MAINTAIN THE QUALITY AND DURABILITY OF BALI BEEF)

\author{
I Ketut Suada ${ }^{1}$, Dimas Indra Dwi Purnama², Kadek Karang Agustina ${ }^{1}$ \\ ${ }^{1}$ Laboratorium Kesehatan Masyarakat Veteriner, Fakultas Kedokteran Hewan \\ Universitas Udayana, Jl. PB. Sudirman Denpasar-Bali. \\ ${ }^{2}$ Praktisi Dokter Hewan di Jawa Timur \\ Email: tutsuada@unud.ac.id
}

\begin{abstract}
ABSTRAK
Daun salam (Syzygium polyanthum) sering digunakan dalam berbagai masakan untuk meningkatkan citarasa, tanpa disadari bahwa daun salam mengandung senyawa antimikroba yang bersifat bakterisidal. Tujuan dari penelitian ini adalah untuk mengetahui khasiat perendaman infusa daun salam terhadap kualitas dan daya tahan daging sapi bali pada peletakkan suhu ruang.. Uji warna menggunakan standar warna Standar Nasional Indonesia daging sapi yang dibaca oleh sepuluh orang panelis, uji bau dan tekstur menggunakan sepuluh orang panelis, uji $\mathrm{pH}$ diukur menggunakan $\mathrm{pH}$ meter, uji kadar air dilakukan dengan metode pengeringan menggunkan oven, selanjutnya uji daya ikat air menggunakan metode Hamm. Hasil penelitian menunjukkan bahwa perlakuan perendaman infusa daun salam dengan konsentrasi $(0 \%, 5 \%, 10 \%$, dan $15 \%)$ berpengaruh sangat nyata terhadap bau, warna, dan tekstur daging sapi bali, lama peletakkan pada suhu ruang berpengaruh sangat nyata terhadap $\mathrm{pH}$ dan kadar air daging sapi bali namun tidak berpengaruh nyata terhadap daya ikat air. Dapat disimpulkan bahwa kualitas dan daya tahan daging sapi bali mampu diperthankan melalui perendaman dengan infusa daun salam.
\end{abstract}

Kata kunci: infusa; bau; warna; tekstur; pH kadar air; daya ikat air; daging sapi bali

\begin{abstract}
Bay leaf (Syzygium polyanthum) is often used in a variety of dishes to enhance the flavor, without realizing that the leaves contain antimicrobial compounds are bactericidal. The purpose of this study was to determine the effect of immersion bay leaves infuse to the quality and durability of beef bali at room temperature laying in terms of odor, color, texture, $\mathrm{pH}$, water content and water holding capacity. Test colors using a color standard ISO beef concluded by the ten panelists, test smells and textures using ten panelists, test the $\mathrm{pH}$ was measured using a $\mathrm{pH}$ meter, test the water content carried by the drying method using the oven, the next test of water holding capacity using methods Hamm. The results showed that soaking treatment bay leaf infusion with concentration $(0 \%$, $5 \%, 10 \%$ and $15 \%$ ) was highly significant to the smell, color, and texture of beef bali, old laying on the temperature the room was highly significant on $\mathrm{pH}$ and water content of beef bali but did not significantly affect water holding capacity. Can be concluded that the quality and endurance of bali beef can maintained by marinated into bay leaves infuse.
\end{abstract}

Keywords: infusion; smell; color; texture; $\mathrm{pH}$, water content; water holding capacity; beef bali

\section{PENDAHULUAN}

Daging merupakan bahan pangan yang penting dalam memenuhi kebutuhan gizi. Selain mutu proteinnya yang tinggi, daging mengandung asam amino esensial yang lengkap dan seimbang, serta beberapa jenis mineral dan vitamin. Daging merupakan protein hewani yang mudah dicerna dibanding dengan protein nabati (Saraswati, 2015). Salah satu daging yang banyak dikonsumsi oleh masyarakat Indonesia yaitu daging sapi. Daging sapi merupakan salah satu bahan pangan asal ternak yang mengandung nutrisi berupa air, protein, lemak, mineral, dan sedikit karbohidrat (glikogen dan glukosa) (Sarassati dan Agustina, 2015). Akibat adanya nutrisi yang terkandung dalam daging sapi, maka daging sapi juga merupakan medium yang baik untuk 
pertumbuhan bakteri, sehingga mudah mengalami kerusakan (Nurwantoro et al., 2012).

Aktifitas mikroba selama penyimpanan mengakibatkan terjadinya dekomposisi senyawa kimia yang dikandung daging, khususnya protein akan dipecah menjadi senyawa yang lebih sederhana dan apabila proses ini berlanjut terus akan menghasilkan senyawa yang berbau busuk, seperti indol, skatol, merkaptan, amin-amin dan $\mathrm{H}_{2} \mathrm{~S}$. Diantara senyawa-senyawa tersebut hanya merkaptan dan $\mathrm{H}_{2} \mathrm{~S}$ yang bersifat asam lemah, selebihnya bersifat basa dan basa kuat. Semakin lama meletakkan daging pada suhu ruang akan semakin banyak basa yang dihasilkan akibat semakin meningkatnya aktivitas mikroorganisme yang pada akhirnya mengakibatkan terjadinya pembusukan. Proses pembusukan akan diikuti dengan peningkatan $\mathrm{pH}$, dan keadaan ini akan diikuti pula dengan peningkatan pertumbuhan bakteri (Suradi, 2012).

Akibat dari pertumbuhan bakteri pada daging yang mengakibatkan kerusakan pada daging, maka perlu dilakukan pengawetan terhadap daging supaya daging memiliki daya simpan yang lebih lama. Pengawetan daging merupakan suatu cara menyimpan daging untuk jangka waktu yang cukup lama agar kualitas maupun kebersihannya tetap terjaga. Tujuan pengawetan adalah menjaga ketahanan terhadap serangan jamur (kapang), bakteri, virus dan kuman agar daging tidak mudah rusak. Ada beberapa cara pengawetan yaitu: pendinginan, pelayuan, pengasapan, pengeringan, pengalengan dan pembekuan (Veerman et al., 2011).

Metode untuk pengawetan daging dapat dilakukan dengan pendinginan juga dapat digunakan zat kimia, misalnya nitrit dan nitrat. Tetapi kejelekan penggunaan zat kimia seperti nitrat kemungkinan bersifat karsinogenik. Pada saat ini telah banyak digunakan bahan alami untuk pengawet bahan pangan karena bahan kimia sintetis mempunyai kelemahan antara lain: adanya racun, sukar terdegaradasi sehingga dapat mengganggu kesehatan (Agustina et al., 2017).

Salah satu bahan alamiah yang dicoba sebagai antimikroba adalah ekstrak daun salam (Syzygium polyanthum). Di tingkat rumah tangga, daun salam sering digunakan dalam berbagai masakan untuk meningkatkan citarasa, tanpa disadari bahwa daun salam mengandung senyawa antimikroba yang bersifat bakterisidal. Komponen antimikroba yang terkandung di dalam daun salam berupa minyak atsiri, tanin, dan flavonoid. Ketiga komponen ini dapat berfungsi sebagai antimikroba karena mengandung gugus $\mathrm{OH}$ yang dapat melunturkan komponen lemak menyusun dinding sel mikroba (Cornelia et al., 2005). Sehingga perlu dilakukan penelitian untuk mengetahui pengaruh perendaman infusa daun salam terhadap kualitas dan daya tahan daging sapi bali yang diletakkan pada suhu ruang ditinjau dari bau, warna, tekstur, $\mathrm{pH}$, kadar air, dan daya ikat air (DIA).

\section{MATERI DAN METODE}

\section{Sampel penelitian}

Sampel daging sapi bali segar diambil di Rumah Pemotongan Hewan Pesanggaran Kota Denpasar, sampel dibungkus dengan kantong plastik steril dan dimasukkan kedalam coolbox yang berisi es. Lalu sampel di bawa ke Laboratorium untuk diuji terhadap pengaruh perendaman infusa daun salam dan peletakkan pada suhu ruang. Sampel dibagi menjadi empat bagian kemudian direndam infusa daun salam dengan konsentrasi $0 \%$, 5\%, $10 \%$ dan $15 \%$ di dalam gelas plastik dengan volume infusa daun salam $300 \mathrm{ml}$ selama 20 menit, ditiriskan selama 15 menit dan kemudian ditempatkan pada plastik steril dan diletakkan pada suhu ruang dengan keadaan plastik tertutup selanjutnya dilakukan pengujian setiap 3 jam sekali, pada jam ke- $0,3,6$, dan 9 . 


\section{Penghitungan berat kering daun salam}

Beberapa helai daun salam yang telah dihaluskan dengan cara dihancurkan dengan mortir, diletakkan dalam cawan kosong yang sebelumnya telah dihitung beratnya $\left(\mathrm{W}_{0}\right)$, kemudian cawan dengan daun salam yang telah dihancurkan ditimbang $\left(\mathrm{W}_{1}\right)$. Masukkan di dalam oven dengan suhu $105^{\circ} \mathrm{C}$ selama \pm 3 jam lalu didinginkan. Selanjutnya cawan tersebut ditimbang $\left(\mathrm{W}_{2}\right)$ dan berat kering dihitung dengan rumus:

Berat Kering $(\%)=\frac{\mathrm{w}_{2}-\mathrm{w}_{0}}{\mathrm{w}_{1}-\mathrm{w}_{0}} \times 100 \%$

$\mathrm{W} 0=$ Berat cawan kosong

$\mathrm{W} 2$ = Berat cawan kosong + Daun salam

$\mathrm{W} 1=$ Berat cawan kosong + Daun salam setelah di oven

\section{Pembuatan infusa daun salam}

Daun salam dibersihkan kemudian diiris kecil-kecil, dikeringkan terlebih dahulu sebelum direbus. Konsentrasi daun salam yang digunakan pada penelitian ini adalah perbandingan $0 \%(\mathrm{~b} / \mathrm{v}), 5 \%(\mathrm{~b} / \mathrm{v})$, $10 \%(\mathrm{~b} / \mathrm{v}), 15 \%(\mathrm{~b} / \mathrm{v})$, yaitu $0 \mathrm{~g}, 15 \mathrm{~g}, 30 \mathrm{~g}$ dan $45 \mathrm{~g}$ daun salam yang masing-masing direbus dalam $300 \mathrm{ml}$ air yang telah mendidih selama 10 menit, setelah direbus kemudian airnya disaring dan didinginkan untuk menghilangkan ampas daun salam (Handa et al., 2008; Varma, 2016).

\section{Rancangan penelitian}

Penelitian ini menggunakan Rancangan Acak Kelompok (RAK) pola faktorial yaitu empat faktor konsentrasi $0 \%, 5 \%, 10 \%$, dan $15 \%$ infusa daun salam (Syzygium polyanthum) dengan empat faktor lama peletakkan pada suhu ruang yaitu jam ke 0, 3, 6, dan 9. Pengamatan dimulai pada jam ke-0, jam ke-3, jam ke-6 sampai jam ke-9. Setiap kombinasi perlakuan diulang sebanyak lima kali; sehingga jumlah sampel keseluruhan yang diperlukan 4 x 4 × $5=80$.

\section{Penetapan bau daging}

Untuk penetapan bau daging dilakukan dengan indra penciuman. Daging sapi diletakkan di atas piring kertas sebanyak 5 gram selanjutnya dibaui, dan disimpulkan oleh panelis yang berjumlah 10 orang yang memiliki penciuman yang baik serta panelis merupakan mahasiswa/i yang sedang kuliah di Fakultas Kedokeran Hewan Universitas Udayana. Kriteria penilaian sebagai berikut untuk bau segar dengan skor empat, bau daun salam dengan skor tiga, bau amis dengan skor dua, dan bau busuk dengan skor satu. Panelis akan menulis hasilnya di kuisioner yang telah disediakan.

\section{Penetapan warna daging}

Penilaian warna daging dengan melihat warna daging dan dicocokkan dengan standar warna Standar Nasional Indonesia (SNI). Daging sapi diletakkan di atas piring kertas sebanyak 5 gram selanjutnya menilai dengan melihat warna daging sapi, dan disimpulkan oleh panelis yang berjumlah 10 orang yang memiliki penglihatan yang baik serta panelis merupakan mahasiswa/i yang sedang kuliah di Fakultas Kedokeran Hewan Universitas Udayana. Nilai skor warna ditentukan berdasarkan standar warna SNI. Nilai warna ditentukan berdasarkan skor warna yang paling sesuai dengan warna daging. Standar warna daging terdiri atas sembilan skor dari merah muda sampai merah tua.

\section{Penetapan tekstur daging}

Penetapan tesktur daging dilakukan dengan perabaan, daging sapi diambil sebanyak 5 gram di atas kertas saring, kemudian dilakukan perabaan oleh panelis yang berjumlah 10 orang yang memiliki indra perabaan yang baik serta tercatat sebagai mahasiswa/i yang sedang kuliah di Fakultas Kedokteran Hewan Universitas Udayana. Kriteria penilaian sebagai berikut untuk tekstur daging yang halus diberikan skor dua dan tekstur daging yang kasar diberikan skor satu. Panelis akan menuliskan hasilnya dikuisioner yang telah disediakan. 


\section{Penetapan pH daging}

Pengukuran $\mathrm{pH}$ pada sampel daging dilakukan menggunakan $\mathrm{pH}$ meter. Alat pH meter dikalibrasi terlebih dahulu dengan mencelupkan elektroda (ujung $\mathrm{pH}$ meter) pada larutan buffer $\mathrm{pH} 4$ dan buffer pH 6,8. Daging sapi ditimbang sebanyak 5 gram, setelah itu daging ditambah dengan akuades 5ml, kemudian dilumatkan menggunakan mortir dan dihomogenkan. Memasukkan $\mathrm{pH}$ meter kedalam campuran tersebut dan membaca angka yang ditunjukkan oleh $\mathrm{pH}$ meter setelah angkanya tetap. Jika $\mathrm{pH}$ meter telah selesai digunakan, elektroda (ujung $\mathrm{pH}$ meter) tersebut langsung dibilas dengan akuades, dilap dengan tisue dan dikeringkan.

\section{Penetapan kadar air daging}

Pengukuran kadar air dilakukan dengan cara mengeringkan daging di dalam oven pada suhu $105^{\circ} \mathrm{C}$ selama \pm 2 jam. Pertama-tama cawan pengering ditimbang pada neraca analitik, kemudian cawan tersebut dimasukkan ke dalam oven dengan suhu $105^{\circ} \mathrm{C}$, setelah 10 menit cawan dikeluarkan, dan dimasukkan ke dalam desikator, selanjutnya ditimbang beratnya, sampai berat cawan konstan. Jika berat cawan sudah konstan, masukkan daging sebanyak 3 gram ke dalam cawan pengering dan cawan ditimbang beserta daging. Kemudian daging dikeringkan dengan cara memasukkan daging tersebut ke dalam oven pada suhu $105^{\circ} \mathrm{C}$ selama \pm 2 jam, cawan dikeluarkan dan didinginkan kemudian ditimbang sampai berat cawan beserta sampel konstan. Kadar air dihitung dengan rumus:

Kadar Air $(\%)=\frac{\text { Berat Awal }- \text { Berat Akhir }}{\text { Berat Awal }} \times 100 \%$

\section{Penetapan daya ikat air (DIA) daging}

Mengukur daya ikat air dilakukan dengan cara penekanan. Daging sapi ditimbang sebanyak 5 gram. Kemudian daging tersebut diletakkan dalam lipatan kertas yang menyerap air diantara dua lempengan kaca, lalu ditekan dengan baban seberat $35 \mathrm{Kg}$. Kemudian dibiarkan selama 10 menit dan setelah selesai, daging sapi dikeluarkan dari lempengan kaca dan kertas penyerap air, kemudian ditimbang beratnya. Daya ikat air (DIA) dihitung dengan rumus:

Daya lkat Air $(D I A)(\%)=\frac{\text { Berat Residu }}{\text { Berat Awal }} \times 100 \%$

\section{Analisis Data}

Data hasil pengujian bau, warna, dan tekstur dianalisis dengan uji Friedman dan apabila berbeda nyata dilanjutkan uji Wilcoxon sedangkan $\mathrm{pH}$, kadar air, dan daya ikat air (DIA) daging dianalisis dengan sidik ragam dan apabila terdapat perbedaan yang nyata, maka dilanjutkan dengan uji Duncan.

\section{HASIL DAN PEMBAHASAN}

\section{Hasil}

Untuk penetapan hasil uji bau, warna dan tekstur daging sapi bali dilakukan dengan indra penciuman dan disimpulkan oleh panelis yang berjumlah sepuluh orang. Dari hasil penelitian didapatkan hasil Uji Friedman seperti pada Tabel 1. Sementara hasil uji pH, Kadar Air dan Daya Ikat Air diperoleh hasil Sidik Ragam yang tersaji pada Tabel 2 .

Hasil analisis data Uji Friedman terhadap bau, warna maupun tekstur daging sapi bali (Tabel 1) menunjukkan lama peletakkan pada suhu ruang dan konsentrasi infusa daun salam berpengaruh sangat nyata $(\mathrm{P}<0,01)$. Maka dilanjutkan dengan Uji Wilcoxon yang disajikan pada Tabel 3 dan Tabel 4.

Hasil dari uji wilcoxon (Tabel 3) menunjukkan bau pada jam ke-0 sampai jam ke-3 tidak berbeda nyata $(\mathrm{P}>0,05)$, bau pada jam ke-3 sampai jam ke-6 berbeda sangat nyata $(\mathrm{P}<0,01)$, dan bau pada jam ke-6 sampai jam ke-9 berbeda nyata $(\mathrm{P}<0,05)$. Pada Tabel 4 diketahui bahwa bau daging sapi bali pada konsentrasi $0 \%$ dengan 5\% tidak berbeda nyata $(\mathrm{P}>0,05)$, bau pada konsentrasi $5 \%$ dengan konsentradi $10 \%$ berbeda sangat nyata $(\mathrm{P}<0,01)$ sedangkan bau pada konsentrasi $10 \%$ dengan konsentrasi $15 \%$ tidak berbeda nyata $(\mathrm{P}>0,05)$. Hal ini dikarenakan kemungkinan bakteri yang 
tumbuh pada daging perendaman infusa daun salam konsentrasi $0 \%$ dan konsentrasi $5 \%$ mengalami pertumbuhan yang sangat cepat sehingga daging dari bau segar berangsur berubah bau amis selama peletakkan pada suhu ruang. Jika daging didiamkan dalam suhu ruang selama lebih dari 20 menit, maka bakteri bisa membelah (Madruga, 1999).

Tabel 1. Hasil Uji Friedman Terhadap Bau, Warna dan Tekstur Daging Sapi Bali

\begin{tabular}{llcccc}
\hline Parameter & \multicolumn{1}{c}{ Perlakuan } & N & DB & $X^{2}$ & Sig. \\
\hline Uji Bau & Peletakan pada suhu ruang & 20 & 3 & 29,276 & 0,0 \\
& Konsentrasi Infusa & 20 & 3 & 18,000 & 0,0 \\
Uji Warna & Peletakan pada suhu ruang & 20 & 3 & 44,302 & 0,0 \\
& Konsentrasi Infusa & 20 & 3 & 58,628 & 0,0 \\
Uji Tekstur & Peletakan pada suhu ruang & 20 & 3 & 22,000 & 0,0 \\
& Konsentrasi Infusa & 20 & 3 & 18,882 & 0,0 \\
\hline
\end{tabular}

Tabel 2. Hasil Uji Ragam Nilai pH, Kadar Air dan Daya Ikat Air Daging Sapi Bali dengan Pengaruh Konsentrasi Infusa Daun Salam pada Peletakkan Suhu Ruang

\begin{tabular}{llccc}
\hline \multicolumn{1}{c}{ Parameter } & Keragaman & DB & F & Sig. \\
\hline Nilai pH & Konsentrasi & 3 & 1,174 & 0,327 \\
& Lama Peletakkan & 3 & 7,502 & 0,000 \\
& Konsentrasi*Lama Peletakkan & 9 & 0,816 & 0,604 \\
& Galat & 64 & - & - \\
& Total & 79 & 9,492 & 0,931 \\
\hline Kadar Air & Konsentrasi & 3 & 2,238 & 0,092 \\
& Lama Peletakkan & 3 & 15,986 & 0,000 \\
& Konsentrasi*Lama Peletakkan & 9 & 0,408 & 0,927 \\
& Galat & 64 & - & - \\
& Total & 79 & 18,632 & 1,019 \\
\hline Daya Ikat Air & Konsentrasi & 3 & 0,911 & 0,441 \\
& Lama Peletakkan & 3 & 1,009 & 0,395 \\
& Konsentrasi*Lama Peletakkan & 9 & 0,293 & 0,974 \\
& Galat & 64 & - & - \\
& Total & 79 & 36.555 & 1,81 \\
\hline
\end{tabular}

Tabel 3. Hasi Uji Wilcoxon terhadap Bau, Warna dan Tekstur Daging Sapi Bali pada Peletakan Suhu Ruang

\begin{tabular}{lcccc}
\hline \multirow{2}{*}{ Parameter } & \multirow{2}{*}{ Analisis } & $\begin{array}{c}\text { Jam ke-3 - } \\
\text { Jam ke-0 }\end{array}$ & $\begin{array}{c}\text { Jam ke-6 - } \\
\text { Jam ke-3 }\end{array}$ & $\begin{array}{c}\text { Jam ke-9 - } \\
\text { Jam ke-6 }\end{array}$ \\
\hline Bau & Z & $0.000^{\mathrm{a}}$ & $-2.842^{\mathrm{b}}$ & $-2.375^{\mathrm{b}}$ \\
\multirow{3}{*}{ Warna } & Sig. (2-tailed) & 1.000 & 0.004 & 0.018 \\
& Z & $-3.731^{\mathrm{a}}$ & $-2.004^{\mathrm{a}}$ & $-2.177^{\mathrm{a}}$ \\
\multirow{4}{*}{ Tekstur } & Sig. (2-tailed) & 0.000 & 0.045 & 0.029 \\
& Z & $0.000^{\mathrm{a}}$ & $-1.414^{\mathrm{b}}$ & $-2.565^{\mathrm{b}}$ \\
& Sig. (2-tailed) & 1.000 & 0.157 & 0.010 \\
\hline
\end{tabular}


Tabel 4. Hasi Uji Wilcoxon terhadap Bau, Warna dan Tekstur Daging Sapi Bali pada Konsentrasi Infusa Daun Salam

\begin{tabular}{lcccc}
\hline \multirow{2}{*}{ Parameter } & Analisis & $\begin{array}{c}\text { Konsentrasi 5\% - } \\
\text { Konsentrasi 0\% }\end{array}$ & $\begin{array}{c}\text { Konsentrasi 10\% - } \\
\text { Konsentrasi 5\% }\end{array}$ & $\begin{array}{c}\text { Konsentrasi 15\% - } \\
\text { Konsentrasi 10\% }\end{array}$ \\
\hline Bau & Z & $-0.571^{\mathrm{a}}$ & $-2.850^{\mathrm{b}}$ & $0.000^{\mathrm{c}}$ \\
& Sig. (2-tailed) & 0.568 & 0.004 & 1.000 \\
Warna & $\mathrm{Z}$ & $-3.924^{\mathrm{a}}$ & $-3.787^{\mathrm{a}}$ & $-3.937^{\mathrm{a}}$ \\
& Sig. (2-tailed) & 0.000 & 0.000 & 0.000 \\
\multirow{2}{*}{ Tekstur } & Z & $-2.530^{\mathrm{a}}$ & $-1.633^{\mathrm{a}}$ & $0.000^{\mathrm{b}}$ \\
& Sig. (2-tailed) & 0.011 & 0.102 & 1.000 \\
\hline
\end{tabular}

\section{Pembahasan}

Daging yang diletakkan pada suhu ruang selama berjam-jam akan mengalami pertumbuhan bakteri yang sangat cepat dan menyebabkan kerusakan protein pada daging sehingga mengalami perubahan bau pada daging. Produk degradasi pada daging akan melepaskan gas-gas bau seperti amonia, hidrogen, sulfida, serta metil merkaptan (Suardana dan Swacita, 2009). Sedangkan pada perendaman infusa daun salam konsentrasi $10 \%$ dan konsentrasi $15 \%$ tidak mengalami perubahan bau dikarenakan kandungan tanin yang terdapat pada infusa daun salam konsentrasi $10 \%$ dan $15 \%$ lebih tinggi sehingga dapat menghambat bakteri yang menyebabkan daging mudah busuk. Tanin merupakan growth inhibitor sehingga banyak mikroorganisme yang dapat dihambat pertumbuhannya oleh tanin. Tanin yang juga merupakan senyawa fenon bekerja dengan cara menghambat pertumbuhan bakteri dengan melakukan denaturasi protein dan menurunkan tegangan permukaan, sehingga permeabilitas bakteri meningkat. Kerusakan dan peningkatan permeabilitas sel bakteri menyebabkan pertumbuhan sel menjadi terhambat dan akhirnya dapat menyebabkan kematian sel (Kusumaningrum et al., 2013).

Hasil uji wilcoxon (Tabel 3) menunjukkan bahwa warna daging sapi bali pada jam ke-0 sampai jam ke-3 berbeda sangat nyata $(\mathrm{P}<0,01)$, sedangkan warna daging sapi bali pada jam ke-3 sampai jam ke-6 dan jam ke-6 sampai jam ke-9 berbeda nyata $(\mathrm{P}<0,05)$. Hasil uji wilcoxon (Tabel 4) menunjukkan bahwa warna daging sapi bali pada perendaman infusa daun salam konsentrasi $0 \%$ dengan $5 \%$ berbeda sangat nyata $(\mathrm{P}<0,01)$, pada konsentrasi $5 \%$ dengan $10 \%$ menunjukkan berbeda sangat nyata $(\mathrm{P}<0,01)$, dan pada perendaman infusa daun salam pada konsentrasi $10 \%$ dengan $15 \%$ berbeda sangat nyata $(\mathrm{P}<0,01)$ juga. Hal ini menunjukkan bahwa pada infusa daun salam konsentrasi 0\% warna daging masih segar, pada konsentrasi selanjutnya berangsur warna menjadi agak kecoklatan, hal ini dikarenakan adanya pengaruh dari perendaman infusa daun salam yang dimana warna infusa daun salam sendiri yaitu berwarna coklat kehitaman sehingga mempengaruhi warna daging setelah perendaman. Pada penelitian Zulfami et al. (2013) menyatakan bahwa dari hasil perendaman ekstrak kulit nenas pada daging itik tegal afkir mengalami perubahan dari warna awal daging itik afkir putih dan ekstrak kulit nenas agak berwarna kekuningan sehingga proses perendaman antara daging dengan ekstrak kulit nenas membuat daging berwarna cenderung putih kehitaman. Pada penelitian ini peletakkan daging di suhu ruang warna daging mengalami perubahan selama penelitian, dari warna daging pada keadaan segar, berangsur menjadi warna merah agak kecoklat-coklatan. Hal ini disebabkan karena terjadi oksidasi pigmen daging menjadi metmyoglobin (MMb) (Fernandez et al., 2008).

Hasil dari analisis uji wilcoxon (Tabel 3) menunjukkan bahwa tekstur daging sapi bali pada peletakkan suhu ruang jam ke-0 sampai jam ke-3 tidak berbeda nyata $(\mathrm{P}>0,05)$, pada jam ke-3 
sampai jam ke-6 tidak berbeda nyata $(\mathrm{P}>0,05)$, sedangkan tekstur pada jam ke-6 sampai jam-9 berbedan nyata $(\mathrm{P}<0,01)$. Pada Tabel 4 diketahui bahwa tekstur daging sapi bali pada konsentrasi $0 \%$ dengan $5 \%$ berbeda nyata $(\mathrm{P}>0,05)$, tekstur pada konsentrasi 5\% dengan konsentradi $10 \%$ tidak berbeda nyata $(\mathrm{P}>0,05)$, dan tekstur pada konsentrasi $10 \%$ dengan konsentrasi $15 \%$ tidak berbeda nyata $(\mathrm{P}>0,05)$ juga. Antemortem dan postmortem merupakan dua faktor yang mempengaruhi keempukan daging. Faktor antemortem seperti genetik, termasuk bangsa, spesies, dan fisiologi, jenis kelamin, umur, manajemen dan stress (Amertaningtyas, 2012; Merthayasa et al., 2015). Aktivitas mikoba pada suhu ruang dapat mendregasi struktur protein pada daging sehingga tekstur daging bisa berubah (Setyarwadani, 2005; Sembiring et al., 2015).

Dari hasil analisi sidik ragam pada Tabel 2. menunjukkan bahwa lama peletakkan daging sapi bali pada suhu ruang berpengaruh sangat nyata $(\mathrm{P}<0,01)$ terhadap nilai $\mathrm{pH}$ daging sapi bali sedangkan konsentrasi infusa daun salam tidak berpengaruh nyata $(\mathrm{P}>0,05)$ terhadap nilai $\mathrm{pH}$ daging sapi bali. Hasil Uji Duncan terhadap nilai $\mathrm{pH}$ daging sapi bali pada lama peletakkan suhu ruang seperti pada Tabel 5.

Tabel 5. Hasil Uji Duncan Nilai pH Daging Sapi Bali pada Lama Peletakkan Suhu Ruang

\begin{tabular}{cccc}
\hline Waktu & & \multicolumn{2}{c}{ Signifikansi } \\
\cline { 3 - 4 } $\begin{array}{c}\text { peletakan } \\
\text { (Jam) }\end{array}$ & Rataan & 0,05 & 0,01 \\
\hline 0 & 5,9 & $\mathrm{a}$ & $\mathrm{a}$ \\
3 & 5,805 & $\mathrm{~b}$ & $\mathrm{~b}$ \\
6 & 5,785 & $\mathrm{~b}$ & $\mathrm{~b}$ \\
9 & 5,78 & $\mathrm{~b}$ & $\mathrm{~b}$ \\
\hline
\end{tabular}

Keterangan: Nilai dengan huruf yang berbeda kearah kolom menunjukkan berbeda nyata $(\mathrm{P}<0,05)$ atau sangat nyata $(\mathrm{P}<0,01)$, sebaliknya nilai dengan huruf yang sama menunjukkan tidak berbeda nyata $(P>0,05)$ atau sangat nyata $(P>0,01)$.
Hasil uji Duncan pada Tabel 5 menunjukkan bahwa terjadi penurunan $\mathrm{pH}$ daging sapi bali selama peletakkan pada suhu ruang. Pada jam ke-0 sampai jam ke3 menunjukkan perbedaan yang sangat nyata $(\mathrm{P}<0,01)$ namun pada jam ke-3 sampai jam ke-6 dan jam ke-6 sampai jam ke-9 tidak menunjukkan perbedaan nyata $(\mathrm{P}>0,05)$. Nilai $\mathrm{pH}$ yang didapat dari peletakkan pada suhu ruang berturut-turut $5,9,5,805,5,785$, dan 5,78. Hal ini diduga bahwa nilai $\mathrm{pH}$ pada penelitian ini dipengaruhi oleh nilai $\mathrm{pH}$ pada kedua bahan dasar yaitu daging sapi bali yang memiliki nilai $\mathrm{pH}$ 5,8 dan infusa daun salam yang memiliki nilai $\mathrm{pH} 5,4$. Nilai $\mathrm{pH}$ yang hampir sama dari kedua bahan menyebabkan $\mathrm{pH}$ pada perlakuan perendaman infusa daun salam pada daging sapi bali menjadi tidak berbeda terhadap $\mathrm{pH}$ daging sapi bali. Perendaman dengan waktu 20 menit belum mencukupi untuk menurunkan $\mathrm{pH}$ daging.

Lama peletakkan daging pada suhu ruang berpengaruh sangat nyata terhadap penurunan $\mathrm{pH}$ daging. Hal ini diduga dikarenakan daging yang diletakkan pada suhu ruang dimasukkan ke dalam plastik. Dari hasil penelitian Yanti et al. (2008), menyatakan bahwa plastik PE dan PP sebagai bahan kemasan daging sapi segar selama penjualan di Pasar Arenka Kota Pekanbaru dapat menurunkan nilai $\mathrm{pH}$. Semakin rendah $\mathrm{pH}$ suatu produk umumnya akan meningkatkan daya simpan produk karena bakteri akan sulit hidup pada $\mathrm{pH}$ rendah kecuali bakteri yang tahan pada $\mathrm{pH}$ rendah (Achidophilic) (Soeparno, 2005). Kebanyakan mikroorganisme dapat tumbuh pada kisaran $\mathrm{pH}$ 6,0-8,0 dan nilai $\mathrm{pH}$ di luar kisaran 2,0-10,0 biasanya bersifat merusak. Beberapa mikroorganisme dalam bahan pangan tertentu seperti khamir dan bakteri asam laktat tumbuh dengan baik pada kisaran nilai $\mathrm{pH}$ 3,0-6,0 dan sering disebut sebagai asidofil (Sutrisna et al., 2015). 
Tabel 6. Hasil Uji Duncan Kadar Air Daging Sapi Bali pada Lama Peletakkan Suhu Ruang

\begin{tabular}{cccc}
\hline Waktu & & \multicolumn{2}{c}{ Signifikansi } \\
\cline { 3 - 4 } peletakan & Rataan & 0,05 & 0,01 \\
\hline (Jam) & & & a \\
0 & 80,7970 & $\mathrm{a}$ & $\mathrm{a}$ \\
3 & 80,3970 & $\mathrm{a}$ & $\mathrm{b}$ \\
6 & 79,6475 & $\mathrm{~b}$ & $\mathrm{~b}$ \\
9 & 79,5955 & $\mathrm{~b}$ & $\mathrm{~b}$ \\
\hline
\end{tabular}

Keterangan: Nilai dengan huruf yang berbeda kearah kolom menunjukkan berbeda nyata $(\mathrm{P}<0,05)$ atau sangat nyata $(\mathrm{P}<0,01)$, sebaliknya nilai dengan huruf yang sama menunjukkan tidak berbeda nyata $(P>0,05)$ atau sangat nyata $(P>0,01)$.

Dari hasil analisis sidik ragam pada Tabel 2 menunjukkan bahwa lama peletakkan berpengaruh sangat nyata $(\mathrm{P}<0,01)$ terhadap kadar air daging sapi bali. Sedangkan konsentrasi infusa daun salam tidak berpengaruh nyata $(\mathrm{P}>0.05)$ terhadap kadar air daging sapi bali. Semakin lama waktu peletakkan kadar air daging semakin menurun. Hasil Uji Duncan terhadap kadar air daging sapi bali pada lama peletakkan suhu ruang seperti pada Tabel 6.

Hasil uji duncan menunjukkan bahwa terjadi penurunan kadar air daging sapi bali pada peletakkan suhu ruang. Pada jam ke-0 sampai jam ke-3 menunjukkan penurunan yang tidak berbeda nyata $(\mathrm{P}<0,05)$ dan pada jam ke-3 sampai jam ke-6 menunjukkan penurunan yang berbeda sangat nyata $(P>0,01)$, sedangkan pada jam ke-6 sampai jam ke-9 menunjukkan penurunan yang tidak berbeda nyata $(\mathrm{P}>0,05)$. Penurunan kadar air pada daging sapi bali kemungkinan juga dikarenakan oleh penggunaan plastik. Penggunaan plastik PP sebagai pengemas daging dapat mencegah masuknya uap air karena plastik PP mempunyai daya tembus uap air yang lebih rendah dibandingkan plastik PE. Plastik PP juga memiliki daya lindung yang lebih baik terhadap produk yang dikemas. Indonesia adalah negara yang beriklim tropis dengan kelembaban udara yang cukup tinggi, sehingga bila kemasan yang digunakan tidak cukup kedap air maka produk akan terkontaminasi oleh air yang diikuti oleh berbagai kerusakan lainnya (Yanti et al., 2008). Kadar air daging sapi bali pada penelitian ini yang tinggi memiliki ratarata $80,79 \%$ dan kadar air daging yang rendah memiliki rata-rata $79,59 \%$.

Dari hasil analisis sidik ragam pada Tabel 2. menunjukkan bahwa lama peletakkan dan konsentrasi infusa daun salam tidak berpengaruh nyata $(\mathrm{P}>0,05)$ terhadap daya ikat air daging sapi bali. Banyak faktor yang dapat mempengaruhi nilai WHC yaitu $\mathrm{pH}$, bangsa, kelembaban, pelayuan daging, tipe dan lokasi otot, fungsi otot, umur, pakan, dan lemak intramuscular (Prasetyo et al., 2013). Menurut Alvarado and McKee (2007) daya ikat air dipengaruhi oleh $\mathrm{pH}$ daging dimana air yang tertahan didalam otot meningkat sejalan dengan naiknya $\mathrm{pH}$, walaupun kenaikannya kecil. Perbedaan daya ikat air disebabkan oleh perbedaan jumlah asam laktat yang dihasilkan, sehingga $\mathrm{pH}$ didalam otot berbeda. Laju penurunan $\mathrm{pH}$ otot yang cepat akan mengakibatkan daya ikat air menjadi rendah (Soeparno, 2005).

\section{SIMPULAN DAN SARAN}

\section{Simpulan}

Dapat disimpulkan bahwa perendaman menggunakan infusa daun salam dengan mampu mempertahankan kualitas daging sapi bali.

\section{Saran}

Perlu dilakukan penelitian lanjutan terhadap kandungan daun salam yang terdapat pada daging sapi bali pasca perendaman.

\section{UCAPAN TERIMAKASIH}

Ucapan terimkasih disampaikan kepada Kepala Laboratorium Kesehatan Masyarakat Veteriner dan Dekan Fakultas Kedokteran Hewan Universitas Udayana yang telah memfasilitasi pelaksanaan penelitian ini. 


\section{DAFTAR PUSTAKA}

Agustina KK, Sari PH, Suada IK. 2017. Pengaruh perendaman pada infusa daun salam terhadap kualitas dan daya tahan daging babi. Bul. Vet. Udayana. 9(1): 34-41.

Alvarado C, McKee S. 2007. Marination to improve functional properties and safety of poultry meat. J. Appl. Poult. Res. 16:113-120.

Amertaningtyas D. 2012. Kualitas daging sapi segar di pasar tradisional Kecamatan Poncokusumo Kabupaten Malang. J. Ilmu dan Tek. Hasil Ternak. 7(1): 42-47.

Cornelia M, Nurwitri CC, Manissjah. 2005. Peranan ekstrak kasar daun salam (Syzygium polyanthum (Wight) Walp.) dalam menghambat pertumbuhan total mikroba dan Escherichia coli pada daging ayam segar. J. Ilmu. dan Tek. Pangan. 3(2): 35-45.

Fernandez DM, Myers AJ, Scramlin SM, Parks CW, Carr SN, Killiefer J, McKeith FK. 2008. Carcass, meat quality, and sensory characteristic of heavy body weight pigs fed ractopamine hydrochloride (Paylean). J. Anim. Sci. 86: 3544-3550.

Handa SS, Khanuja SPS, Longo G, Rakesh DD. 2008. Extraction technologies for medicinal and aromatic plants. International centre for science and high technology. Myanmar.

Kusumaningrum A, Widiyaningrum $\mathrm{P}$, Mubarok I. 2013. Penurunan total bakteri daging ayam dengan perlakuan perendaman infusa daun salam (Syzygium polyanthum). J. MIPA. 36(1): 14-19.

Madruga MS, Arruda SG, Nascimento JA. 1999. Castration and slaughter age effects on nutritive value of the "mestico" goat meat. J. Meat. Science. 52(2): 119-125.

Merthayasa JD, Suada IK, Agustina KK. 2015. Daya Ikat Air, pH, warna, bau dan tekstur daging sapi bali dan daging wagyu. Indo. Med. Vet. 4(1): 16-24.

Nurwantoro VP, Bintoro AM, Legowo A, Purnomoadi LD, Ambara A, Prokoso S, Mulyani. 2012. Nilai pH, kadar air, dan total Escherchia coli daging sapi yang dimarinasi dalam jus bawang putih. J. Apl. Tek. Pangan. 1(2): 20-22.

Prasetyo H, Padaga MC, Sawitri ME. 2013. Kajian kualitas fisiko kimia daging sapi di pasar Kota Malang. $J$. Ilmu dan Tek. Hasil Ternak. 8(2): 1-8.

Sarassati T, Agustina KK. 2015. Kualitas daging sapi wagyu dan daging sapi bali yang disimpan pada suhu $-19^{\circ} \mathrm{C}$. Indo. Med. Vet. 4(3): 178-185.

Saraswati D. 2015. Pengaruh lama penyimpanan daging sapi pada refrigerator terhadap angka lempeng total bakteri (ALTB) dan keberadaan bakteri Escherishia coli. J. Entropi. 10(1): 967-973.

Setyawardani T, Haryanto I. 2005. Kajian Pengempukan Daging Kambing. $J$. Anim. Prod. 7(2): 106-110.

Sembiring UR, Suada IK, Agustina KK. 2015. Kualitas daging kambing yang disimpan pada suhu ruang ditinjau dari uji subyektif dan obyektif. Indo. Med. Vet. 4(1): 155-162.

Soeparno. 2005. Ilmu dan Teknologi Daging. 4th Ed. Gadjah Mada University Press. Yogyakarta.

Suardana IW, Swacita IBN. 2009. Higiene Makanan. $1^{\text {st }}$ Ed. Udayana University Prees. Denpasar.

Suradi K. 2012. Pengaruh lama penyimpanan pada suhu ruang terhadap perubahan nilai $\mathrm{pH}, \mathrm{TVB}$ dan total bakteri daging kerbau. J. Ilmu. Ternak. 12(2): 9-12.

Sutrisna R, Ekowati CN, Sinaga E. 2015. Pengaruh $\mathrm{pH}$ terhadap produksi antibakteri oleh bakteri asam laktat dari usus itik. J. Penelitian. Pertanian. Terapan. 15(3): 234-238.

Varma N. 2016. Phytoconstituents and their mode of extractions: An overview. Res. J. Chem. Environ. Sci. 4(2): $8-15$ 
Veerman M, Setiyono, Rusman. 2011. Pengaruh metode pengeringan dan konsentrasi bumbu serta lama perendaman dalam larutan bumbu terhadap kualitas kimia dendeng babi. J. Agrinimal. 1(2): 52-59.

Yanti H, Hidayanti, Elfawati. 2008. Kualtitas daging sapi dengan kemasan plastik PE (Polyethylen) dan plastik PP
(Polypropylen) di pasar Arengka Kota Pekanbaru. J. Peternakan. 5(1): 22-27. Zulfahmi M, Pramono YB, Hintono A. 2013. Pengaruh marinasi ekstrak kulit nenas (Ananas Comocus L. Merr) pada daging itik tegal betina afkir terhadap kualitas keempukan dan organoleptik. J. Pangan dan Gizi. 4(8): 19-26. 